\title{
Mané Garrincha como Síntese da Identidade do Futebol Brasileiro
}

\author{
Tiago Lisboa Bartholo*
}

Antonio Jorge Gonçalves Soares**

\begin{abstract}
Resumo: O objetivo do artigo é analisar a biografia do exjogador de futebol Garrincha como expressão de uma trajetória individual que encarna significados coletivos sobre o futebol nacional e sobre o "ser brasileiro". Utilizamos como fonte o livro de Ruy Castro "Estrela solitária: Um brasileiro chamado Garrincha". A análise demonstra que a biografia se transforma em um discurso identitário essencialista. $\mathrm{A}$ ancestralidade indígena é chave para interpretar tanto a exuberância e simplicidade do seu futebol, quanto seu comportamento avesso às normas sociais e a disciplina nos treinamentos. O dom e o sucesso no futebol independem, na leitura cultural realizada pelo biógrafo, do treino, da perseverança e do aperfeiçoamento.
\end{abstract}

Palavras-chave: Futebol. Identidade Nacional. Garrincha. Biografia.

\section{INTRODUÇÃo}

O discurso identitário sobre o futebol brasileiro funda sua singularidade afirmando possuir um estilo de jogo alegre e bonito. A arte do drible, com a "ginga da capoeira" e com o ritmo do samba seriam as principais marcas de reconhecimento. A afirmação desse estilo vem sendo construída numa luta simbólica em relação a "outros estilos", desde a segunda década do século XX (SOARES; LOVISOLO, 2003). O estilo brasileiro (beautiful game) é narrado como um modo singular de uso do corpo, uma técnica corporal, ora interpretada como socializada culturalmente (MAUSS, 1974), ora como um produto

\footnotetext{
* Mestre em Educação Física pela Universidade Gama Filho, professor do Colégio de Aplicação da Universidade Federal do Rio de Janeiro e bolsista do CNPq. Rio de Janeiro, RJ, Brasil. E-mail: tbartholo81@hotmail.com

** Doutor em Educação Física pela Universidade Gama Filho, professor do Programa de PósGraduação em Educação Física da Universidade Gama Filho, professor da Universidade Federal do Rio de Janeiro e bolsista do CNPq/ PROTEORIA. E-mail: antoniojsoares@pq.cnpq.br
} 
da miscigenação racial na versão da fábula das três raças, na qual o cultural se confunde com a expressão biológica. Em outros termos, a expressão cultural seria fortemente determinada pelo biológico. A interpretação racialista, apesar de nem sempre explícita, é a narrativa dominante sobre o estilo de jogo e de música - leia-se especificamente o samba - no Brasil. Todavia, devemos apontar que tanto a construção quanto a manutenção das narrativas identitárias se assentam na memória coletiva.

A construção do estilo brasileiro alargou-se pelo mundo e sua beleza e encantamento são louvados por jornalistas e torcedores de países onde o futebol é o esporte dominante. Criou-se, por assim dizer, um capital cultural esportivo em torno do futebol brasileiro que, entre outros indicadores, resulta em significativa demanda internacional de jogadores, de técnicos e de desafios festivos, além dos determinados pelos calendários oficiais (DAMO, 2005).

A tradição do futebol brasileiro é lembrada em diferentes meios de divulgação. As biografias dos jogadores parecem-nos espaços privilegiados para compreendermos a forma como essa tradição é construída, pois os autores devem criar motivos e racionalizações para dar sentido às trajetórias individuais. Noutra direção, os autores destacam traços e aspectos singulares da vida de certos jogadores que acabam por revelar valores e significados coletivos da cultura na qual o biografado está inserido. Como atesta Helal e Murad (1995, p. 68) "a biografia de um herói contém, sem dúvida, mensagens e revelações importantes da cultura de um povo".

O objetivo do artigo é analisar a biografia do ex-jogador de futebol Garrincha - cujo nome de batismo é Manuel dos Santos como expressão de uma trajetória individual que encarna significados coletivos sobre o futebol brasileiro e sobre o "ser brasileiro". A biografia escrita por Ruy Castro (1995), "Estrela solitária: um brasileiro chamado Garrincha", constitui-se no objeto de análise deste artigo. Estamos especialmente interessados em entender como o autor opera

${ }^{1}$ Ruy Castro, nascido em 1948, é jornalista e tem uma extensa carreira literária. Destacamos entre seus livros: Ela é carioca: uma enciclopédia de Ipanema (1999), O anjo pornográfico: a vida de Nelson Rodrigues (1992) e Chega de saudade: a história e as histórias da Bossa Nova (1990), todos editados pela editora Companhia das Letras.

Movimento, Porto Alegre, v. 15, n. 01, p. 169-191, janeiro/março de 2009. 
com as lembranças e os esquecimentos para narrar a trajetória de Garrincha dentro e fora dos gramados. Nossa análise irá acompanhar a biografia de Garrincha desde a infância do jogador em sua cidade natal, Pau Grande, até o ano de 1963 - início do declínio da carreira futebolística.

A escolha desse jogador não é fortuita. Garrincha seria a tradução e a encarnação do jogo bonito (beautiful game). A imagem de Garrincha é a do atleta que não valoriza esquemas táticos ou treinamentos físicos. Seu sucesso dentro dos campos de futebol é narrado como expressão de um dom ante as adversidades enfrentadas. Ruy Castro escreve uma bela e consistente história sobre a trajetória de Garrincha, que, nas sombras da narrativa, revela a construção hegemônica e homogeneizadora da identidade do futebol brasileiro.

Destacamos cinco categorias de análise que serão debatidas ao longo deste capítulo: 1) trabalho/treino; 2) liberdade; 3) “dom"; 4) atrevimento/inocência da criança; 5) "apetite sexual". Esses são os elementos difundidos por Castro (1995) para apresentar Garrincha.

\section{A origem do «DOM» DE MANUel dos SANTOS}

Para contar a trajetória do jogador de futebol Garrincha, Ruy Castro volta ao ano de 1865 e relembra os antepassados do atleta. Garrincha era descendente de índios da aldeia fulniô, nasceu no ano de 1933 em uma pequena cidade no estado do Rio de Janeiro (Brasil), Pau Grande, ${ }^{2}$ e, como todos os garotos da sua idade, brincava nas matas e nos rios que cercavam a cidade. As representações de Castro (1995) sobre Garrincha são a do bom selvagem, da liberdade e da ingenuidade da vida rural ou natural, em oposição à vida urbana; liberdade versus coerção; espontaneidade versus artificialidade.

\footnotetext{
Vivia descalço - suas solas dos pés, desde sempre, eram as de quem andava no mato e nos calçados de pedra (CASTRO, 1995, p. 27).
}

\footnotetext{
2 Pau Grande é um pequeno distrito no município de Magé, distante 70 quilômetros da capital, Rio de Janeiro. Na década de 1920, a economia da cidade girava em torno da fábrica de tecidos inglesa América Fabril, que estava se estabelecendo na região. A área do distrito ainda era área rural, com ruas de barro e muita área verde.

Movimento, Porto Alegre, v. 15, n. 01, p. 169-191, janeiro/março de 2009.
} 
Garrincha era o nome de um passarinho indomável que não se acostumava ao cativeiro. Era uma espécie bem comum na região [...] Garrincha também não se adaptava ao cativeiro. Até os sete anos, sua vida foi caçar passarinhos, tomar banho no rio e jogar pelada (CASTRO, 1995, p. 28).

Segundo Castro (1995, p. 30), o gosto do menino pelo futebol foi cedo despertado: "[...] Não precisava ser dono da bola para garantir seu lugar nas peladas - já era melhor que todos os moleques da rua". A expressão o "dono da bola" tem um duplo sentido no Brasil, tanto significa a forma pela qual os praticantes com poucas habilidades corporais participam do jogo, pelo fato de possuírem o implemento do esporte, a bola, que viabiliza o jogo; quanto uma espécie de crítica a algum jogador que integra uma equipe e sobre ele paira a desconfiança de suas qualidades ou habilidades como jogador. Em outras palavras, significa que o "dono da bola" é, em última instância, aquele que não tem competência para o esporte. A ideologia das sociedades individualistas, que se reflete de forma bem nítida no esporte, afirma que os indivíduos devem conquistar seu espaço na sociedade por suas competências e não a partir de suas posses e/ou origem social. Garrincha é nesse caso alguém que se afirma desde cedo pela competência inconteste.

Ao longo dos primeiros capítulos do livro, Castro (1995) constrói a imagem de um menino que, desde cedo, se mostrava avesso às regras sociais e tinha o "dom" de jogar futebol por ter como ancestrais os índios ${ }^{3}$ e, exatamente por isso, era indomável.

Amaro e Maria Carolina deram-se conta de que tinham um filho vivendo em estado quase selvagem. [...] A partir dali, começaram a tentar civilizá-lo (CASTRO, 1995, p. 31).

E a civilização não era o elemento de Garrincha. A graça estava em driblar, apenas driblar. Estava no futebol em estado selvagem e lúdico, que era como os índios o jogariam, se soubessem (CASTRO, 1995, p. 64).

\footnotetext{
${ }^{3}$ Lembremos que na história do Brasil o índio - essa palavra genérica para indicar diferentes grupos étnicos - é representado como um ser indomável que não se deixou escravizar pelo colonizador europeu.

Movimento, Porto Alegre, v. 15, n. 01, p. 169-191, janeiro/março de 2009.
} 
Os valores românticos que estruturam a narrativa são evidentes, índio e vida natural foram topos do romantismo brasileiro. Observe-se que os "antecedentes étnicos" servem para Castro (1995) interpretar a suposta inadequação de Garrincha aos esquemas táticos e à consequente falta de disciplina e ascetismo que requer o ethos de um atleta profissional. Percebamos que essas imagens sobre Garrincha não foram, de forma nenhuma, inventadas por Ruy Castro; podemos encontrar, em vários cronistas e jornalistas esportivos, esse tom romântico. Mário Filho, jornalista e construtor do campo do jornalismo esportivo no Brasil, descrevia Garrincha pelas mesmas lentes românticas (LEITE LOPES, 1994; SOARES, 1998).

A leitura que Castro realiza do futebol de Garrincha remete a um "outro", istoé, ao futebol de disciplina tática, jogado pelos ingleses ou, de forma mais englobadora, pelos “europeus". Não há provas de que outros jogadores, nacionais ou estrangeiros, fossem tão disciplinados para termos uma estrutura dicotômica: disciplinado versus indisciplinado. De fato, disciplina e indisciplina parecem formar pólos opostos de um contínuo, e não sabemos se Garrincha ocupava um de seus extremos. Mas, no plano narrativo de Castro, o pólo da indisciplina serve para destacar a ruptura estética que assume o futebol de Garrincha em relação ao "futebol convencional" e ascético dos "outros".

Se até aqui temos a origem de Garrincha construída pelas lentes românticas - a trajetória de um menino à "margem da civilização" -, em outros momentos da biografia o próprio autor apresenta dados que indicam que Garrincha seguia normas e comportamentos sociais partilhados. Por exemplo, foi matriculado na escola aos 7 anos idade igual a dos outros meninos de Pau Grande -, em um período em que boa parte dos brasileiros não freqüentava o ensino fundamental, e começou a trabalhar na fábrica da cidade, América Fabril, ${ }^{4}$ com 14 anos, ${ }^{5}$ a mesma idade dos seus colegas. Garrincha parece ter tido, pela descrição de Castro (1995), uma infância e uma adolescência semelhantes aos seus contemporâneos, todavia, a ênfase na expressão do gênio, do artista de vanguarda da bola sobrepõe-se à

\footnotetext{
${ }^{4}$ A América Fabril era uma fábrica têxtil de donos ingleses. Castro (1995) afirma que boa parte da economia local da pequena Pau Grande girava em torno da fábrica.

${ }^{5}$ Ano que se outorga a entrada no mundo do trabalho na função de "aprendiz".

Movimento, Porto Alegre, v. 15, n. 01, p. 169-191, janeiro/março de 2009.
} 
trajetória terrena e ordinária seguida por Garrincha e por vários jogadores do seu tempo. O biografado, para afirmar-se como jogador, como poderá ser visto mais adiante, teve perseverança de submeterse a testes, sendo rejeitado em vários até conseguir por fim a aprovação num clube profissional. Temos, assim, na descrição de Castro (1995), a trajetória do herói (PROPP, 1984). A idéia de "destino" presente na biografia de Garrincha pode ser observada de forma clara em outros atletas consagrados do esporte brasileiro. ${ }^{6}$

Garrincha começou sua vida no futebol como jogador e operário de um clube de fábrica têxtil. As pesquisas indicam que os clubes de fábrica e a prática do futebol eram instituições difundidas em boa parte do século XX no Brasil (ANTUNES, 1992). Apesar de Garrincha ter iniciado sua carreira no futebol a partir de um clube de fábrica, no qual esporte e trabalho eram conjugados, Castro (1995) insiste em ressaltar a imagem de que seu biografado era avesso às normas sociais e "indomável”. Assim, narra o biógrafo, Garrincha foi advertido, demitido e recontratado algumas vezes pela América Fabril. O Sport Clube Pau Grande, clube de futebol mantido pela fábrica inglesa, dependia da competência do jogador de futebol Garrincha, e somente funcionários podiam participar dos torneios segundo os critérios da liga de futebol. Castro enfatiza que Garrincha, apesar de não ter a disciplina como trabalhador/operário, era o principal jogador da equipe da fábrica e isso o mantinha empregado.

Castro busca explicações para as qualidades apresentadas por Garrincha no campo de futebol:

A expressão gênio intuitivo não devia ser moeda
corrente na serra dos Órgãos nos anos 40. Mas era
a única explicação para o futebol do jovem Garrincha.
De onde ele tirara aquele jeito de arrancar, driblar e
chutar? Não havia grandes antecedentes futebolís-
ticos na família. [...] Aos doze anos, em 1945,
Garrincha já jogara mais peladas ${ }^{7}$ do que fizera qual-
quer outra coisa na vida. Eram, no mínimo, duas ou

${ }^{6}$ Sobre Romário ver Guedes (1998). Vaz (2002) analisa a trajetória de Pelé e Ayrton Senna. Conferir Bartholo (2007) sobre a trajetória do tenista Gustavo Kuerten.

7 O sentido da palavra "pelada" na linguagem nativa significa jogo informal de futebol. A organização desses jogos dá-se espontaneamente pelos atores sociais envolvidos com a flexibilização das regras do jogo.

Movimento, Porto Alegre, v. 15, n. 01, p. 169-191, janeiro/março de 2009. 
três por dia - no futuro, ele manteria essa regularidade, só que em outro esporte (CASTRO, 1995, p. $38)$.

Se seguirmos as indicações de Castro ficaremos em dúvida: afinal, Garrincha era grande jogador porque jogava muito tempo ou jogava muito porque era grande? Em outros termos, suas habilidades eram produtos da intensidade do treinamento, da aprendizagem na prática, ou do dom? Castro (1995) afirma que Garrincha tinha grande prazer em praticar futebol e passava a maior parte do seu tempo jogando partidas com seus colegas. Entretanto, apresenta o biografado como alguém que tinha recebido um "dom" para jogar futebol, teria, então, "qualidades naturais", sem antecedentes familiares na prática do esporte. No caso de Garrincha, o ditado popular "filho de peixe, peixinho é" não se aplica. Ruy Castro coloca a prática intensa, embora não orientada tecnicamente, como não sendo treino. A atividade de Garrincha, nas peladas, nos terrenos baldios, é interpretada pelo biógrafo como lazer e prazer, portanto, ficava fora do trabalho orientado por objetivos. No Brasil, o treino é visto como algo estoico para aqueles que não possuem "dom". A construção indica a oposição entre dom e treinamento, criatividade e esforço, liberdade e disciplina. Essas são imagens presentes na cultura brasileira, embora não sejam apenas dela, que aparecem no discurso sobre o futebol.

No futebol, e em outros espaços sociais no Brasil, quando alguém é qualificado como "esforçado" significa dizer que o indivíduo possui poucas habilidades e tenta superar a ausência do dom pelo esforço. Um grande jogador de futebol brasileiro na década de 1980 como Zico foi alvo dessa interpretação em vários momentos de sua carreira (HELAL; SOARES; LOVISOLO, 2001). Isso não indica que o esforço individual seja desvalorizado no cenário cultural, o problema de ordem cultural, em termos hegemônicos, é que o dom se opõe ao esforço. O dom faz o gênio. Em outra mão, essa oposição estrutural apresenta-se ambígua e é deslizante em nível discursivo, pois a ausência do esforço serve, em determinados momentos, para explicar o insucesso daquele que "nasceu" com dom e com todas as condições para dar expressão à sua genialidade. Pode-se perder a genialidade por falta de esforço, mas não se pode ser gênio apenas com o esforço.

Movimento, Porto Alegre, v. 15, n. 01, p. 169-191, janeiro/março de 2009. 
Garrincha é posto como o gênio que recusa o esforço. Assim, é duplamente gênio ou hipergênio, por sê-lo sem esforço.

A infância pobre, mas feliz, de Garrincha em uma pequena cidade do estado do Rio de Janeiro é enfatizada pelo biógrafo. A falta de brinquedos caros como patinete ou velocípede é destacada no livro. O jogo de futebol é visto por Castro (1995) como uma brincadeira que não exige altos custos, a dizer, está ao alcance dos mais pobres. Garrincha jogava peladas na várzea descalço e encarna a trajetória clássica de muitos ídolos do futebol que vencem a pobreza a partir do "dom".

\section{OS PRIMEIROS PASSOS NO FUTEBOL PROFISSIONAL}

Garrincha teve sua primeira chance em um time do Rio de Janeiro aos 19 anos, fato raro na época (CASTRO, 1995). Em geral, os garotos chegavam aos clubes com 13 ou 14 anos para fazer testes. Ruy Castro, nesse momento, mostra as dificuldades encontradas por Garrincha para iniciar sua carreira como jogador profissional de futebol. O biógrafo relata que Garrincha fora reprovado em três testes realizados em importantes clubes do Rio de Janeiro - Vasco, São Cristóvão e Fluminense -, antes de ser aprovado pelo Botafogo. ${ }^{8}$ Garrincha teria sido vítima da incompreensão dos técnicos, que, apesar de o considerarem bom jogador, não toleravam um "único defeito, facilmente corrigível, que é o de driblar demais" (CASTRO, 1995, p. 64). Aqui o autor apresenta os obstáculos que seu herói trágico viveu para afirmar seu estilo de jogo no futebol, obter sucesso e morrer como louco e alcoólatra. ${ }^{9}$ Pode parecer contraditório o "defeito" de driblar excessivamente com a imagem identitária do futebol brasileiro. Parece que estamos de novo diante de uma oposição romântica de classe. Os jogadores são os artistas, contudo, os técnicos não reconhecem sua arte. São os jogadores os que expressam o autêntico, os técnicos podem estar subjugados a padrões internacionais que enfatizam a disciplina.

\footnotetext{
${ }^{8}$ É prática no Brasil os clubes de futebol realizarem testes com grande contingente de crianças e adolescentes que buscam uma chance de tornarem-se jogadores profissionais de futebol. $\mathrm{O}$ time do Botafogo era, na época de Garrincha e é até os dias atuais, um dos mais importantes times do futebol brasileiro. Para uma história da formação do clube, seus torcedores e as principais conquistas esportivas, conferir Augusto (2004).
}

Movimento, Porto Alegre, v. 15, n. 01, p. 169-191, janeiro/março de 2009. 
A polêmica em torno de qual estilo ou modelo de jogo o futebol brasileiro deve adotar foi objeto de debate pelo menos até a década de 1960, e não era pequeno o número de adeptos ao modelo inglês (SOARES; LOVISOLO, 2003). Os dribles de Garrincha, seu egocentrismo, talvez tenham contribuído para a formação, afirmação e valorização do beautiful game. Contudo, devemos lembrar que o drible é uma técnica valorizada no Brasil quando funcional para o gol ou para a emoção.

Garrincha chegou ao time Botafogo com a indicação de "seu Araty"10 e foi logo apresentado ao treinador do time, Gentil Cardoso, que o pôs para treinar com os titulares. Garrincha agradou. Voltou para Pau Grande como jogador do Botafogo. Nessa passagem, Castro (1995) desconstrói a história, constantemente relembrada na mídia brasileira e nas conversas dos aficionados por futebol, de que Garrincha havia, nesse treino, driblado consecutivamente Nilton Santos. ${ }^{11}$ Castro (1995, p. 58) narra uma luta equilibrada entre os dois jogadores: "O incrível era ter sido um encontro igual, considerando-se que, de um lado, estava Nilton Santos, dezesseis jogos pela seleção brasileira; e, de outro, um jovem desconhecido e torto, que preferia jogar descalço em sua terra e que só calçava chuteira socialmente". O autor pretende corrigir distorções e romantismos presentes na memória oral em favor de apresentar a "verdade". ${ }^{12}$ Contudo, se o confronto entre experiência e genialidade sai empatado, teremos, para o futuro, com a incorporação da experiência, o trunfo da genialidade. Assim, Garrincha é o maior.

Os primeiros anos de Garrincha no Botafogo são narrados como anos de adaptação. Não apenas do jogador ao futebol profissional, mas, também do futebol à Garrincha. Castro (1995) prossegue sua

\footnotetext{
${ }^{9}$ De fato, o terço final da biografia narra a decadência do herói, que morre pobre e esquecido por aqueles que um dia aplaudiram-no de pé, nos grandes palcos do futebol mundial. Ver também Leite Lopes e Maresca (1992).

${ }^{10}$ Uma espécie de "olheiro" - headhunter, pessoa especializada em encontrar novos talentos do Botafogo que o vira jogar futebol em Pau Grande.

${ }^{11}$ Nilton Santos era, na época, considerado um dos melhores jogadores na sua função no Brasil (lateral esquerdo), tendo uma carreira consolidada na seleção brasileira de futebol.

${ }^{12}$ Observe-se que Castro se propõe a fazer uma biografia a partir dos controles do campo da história. Não se pode esquecer que Ruy Castro é jornalista e a idéia de verdade e objetividade da notícia é um valor nesse campo profissional.
}

Movimento, Porto Alegre, v. 15, n. 01, p. 169-191, janeiro/março de 2009. 
narrativa enfatizando que o comportamento de Garrincha era, por vezes, incompreendido por seus companheiros de clube, comissão técnica e jornalistas.

Garrincha driblou a defesa inteira do Cantagalo e, com o gol vazio, deu para o meia Ariosto completar. Ariosto não entendeu nada - por que o próprio Garrincha não fizera o gol?

Esta seria apenas a primeira das perguntas que o Botafogo começaria a fazer sobre Garrincha. Outra: por que, depois de driblar seu marcador e passar por ele, Garrincha esperava de propósito que ele voltasse, para ter de driblá-lo de novo?

Por que essa mania de continuar driblando, quando toda a defesa inimiga já estava destruída?

Ninguém sabia ainda que Garrincha era o profissional mais amador que o futebol poderia produzir. $\mathrm{E}$ que, para ele, a alegria do futebol não estava em fazer gols. Nem vencer a partida. Nem mesmo ganhar o bicho, que era o prêmio em dinheiro pela vitória. Gols, vitórias, bichos, tudo isso eram coisas mesquinhas da civilização (CASTRO, 1995, p. 64, grifos nossos).

Castro (1995) apresenta Garrincha como ruptura artística, como expressão da criatividade no futebol. Por essa razão, o futebol deveria adaptar-se ao estilo do gênio, talvez devesse mudar a estrutura do jogo. No trecho anterior, Garrincha é descrito como um virtuoso e sua habilidade deveria traduzir-se em campo apenas como expressão estética. Os objetivos de vitória eram secundarizados em favor da performance individual. Contudo, há alguma coisa profundamente circense na descrição de Castro na conduta de Garrincha que parece estar dominado pelo quadro no qual o palhaço é enganado repetidas vezes. A dignidade dos defensores devia sofrer profundos abalos. Caçar o enganador podia ser a resposta instintiva dos palhaços.

Durante todo o livro pudemos acompanhar a construção de um homem que praticava futebol porque lhe proporcionava prazer. A dimensão do gosto supera os interesses pela vitória e pela sobrevivência de um homem que vivia desse tipo de trabalho. $\mathrm{O}$ valor da criatividade, do lúdico, confunde-se com a imagem de Garrincha. Vejamos esta passagem escrita por Castro (1995, p. 40):

Movimento, Porto Alegre, v. 15, n. 01, p. 169-191, janeiro/março de 2009. 
Era dinheiro, mas não parecia importar para Garrincha. Com três meses como profissional, cansou-se de subir aos domingos para Petrópolis e deixou o Serrano [clube de futebol da cidade] a ver navios. Esqueceu-se de que assinara um contrato e nunca mais apareceu no clube. Seu time era o Pau Grande, onde jogava de graça.

Garrincha é representado como "jogador amador", aquele que joga apenas por prazer e amor ao esporte. Veremos que essa imagem construída durante todo o livro deve ser relativizada quando acompanhamos os impasses - presentes no próprio texto - na renovação dos contratos com o Botafogo,${ }^{13}$ ou no abandono ao Serrano. ${ }^{14}$ Nesses impasses, Castro (1995) acaba por relatar o interesse do jogador em obter melhores contratos de trabalho. Obter melhores salários é corrente na orientação moral da classe trabalhadora, todavia, Ruy Castro estabelece mediações de modo que Garrincha não apareça como um indivíduo ajustado às regras do mercado de salários no esporte. $\mathrm{O}$ interesse explícito material ou financeiro, no Brasil, não é visto positivamente, ele deve ser escondido, deve ser sutilmente apresentado. Esse traço possui uma dupla influência: a do catolicismo ibérico e do patrimonialismo - no regime escravocrata e capitalista - que regulou as relações no Brasil por muito tempo e ainda hoje encontramos vestígios em plena sociedade democrática (HOLANDA, 1988). Aduzido a isso, a ausência de interesse em Garrincha auxilia no reforço das imagens de pureza e de ingenuidade do gênio que não reconhece seu próprio valor, marcas românticas do discurso. As imagens de pureza e irresponsabilidade - vinculadas a seu jeito de jogar - assemelham Garrincha à figura da criança.

\section{A consagração de GaRRincha}

No seu primeiro ano como profissional pelo Botafogo, Garrincha terminou o campeonato carioca como artilheiro do time - fez 20 gols em 26 partidas. O número indica que era um atacante eficiente

\footnotetext{
${ }^{13}$ Sobre os impasses nas renovações de contrato do jogador, ver páginas: 95-96 e 273-278. ${ }^{14}$ Serrano, clube da cidade de Petrópolis, foi o primeiro time que pagou quantias em dinheiro à Garrincha para que ele jogasse futebol.

Movimento, Porto Alegre, v. 15, n. 01, p. 169-191, janeiro/março de 2009.
} 
e que não deixava de lado o interesse de ganhar. Nos anos seguintes, o Botafogo teve campanhas apenas regulares no campeonato estadual. Ainda iria demorar um pouco até que o time se consagrasse campeão carioca com a contratação de outros importantes jogadores, entre eles Didi, ${ }^{15}$ comprado do Fluminense, que era jogador da seleção brasileira. Observe-se que Didi é apresentado como produto do esforço e do treino em oposição ao dom que Garrincha recebeu de seus ancestrais. Diz Castro (1995, p. 102): "Nada disso era fruto exclusivo de um dom divino. Assim como um pianista ensaia todo dia, Didi ficava treinando passes e cobranças muito depois que seus colegas já tinham ido embora". Assim, ficam marcadas as representações culturais sobre dom e esforço que apresentamos anteriormente.

São inúmeras as passagens em que, ao narrarem Garrincha como irresponsável, retiram o estatuto de adulto do jogador e transformam-no em criança. O biógrafo enfatiza as constantes faltas aos treinamentos do atleta, seus casos amorosos extraconjugais e suas constantes bebedeiras com seus amigos de sua cidade natal: "Sexo era a sua principal ginástica. A outra [Ginástica], a oficial, ele não gostava de fazer. E esta também não era uma grande preocupação dos clubes. Os jogadores treinavam de manhã ou de tarde, nunca em tempo integral" (CASTRO, 1995, p. 75). Apesar de a conduta de Garrincha ser descrita por Castro (1995) como avessa à disciplina e à ordem, o próprio autor diz que Garrincha, nos primeiros anos como jogador profissional, vinha todos os dias de Pau Grande para o Rio de Janeiro treinar. A viagem podia levar até 3 horas. Castro (1995, p. 75) narra grandes temporadas que Garrincha fez como jogador do Botafogo e enfatiza que o seu preparo físico era elogiado pelos médicos e preparadores do time.

Garrincha chegou ao Botafogo no limite da sua fase de desenvolvimento muscular. Com os exercícios, encorpou tudo o que faltava. Nos dois primeiros anos, não cresceu nenhum centímetro em estatura, mas ganhou dois quilos de músculos nas pernas.

${ }^{15}$ Didi nasceu em 8 de outubro de 1928. Participou da equipe campeã da Copa do Mundo de futebol de 1958. Ver Toledo (2004).

Movimento, Porto Alegre, v. 15, n. 01, p. 169-191, janeiro/março de 2009. 
Em pouco tempo Dr. Nova Monteiro diria que elas tinham uma massa muscular "comparável à de um cavalo".

Um paradoxo parece confrontar-nos neste momento: como pode um homem não treinar e ganhar músculos? Como pode não treinar e consagrar-se artilheiro do time? Pela descrição das qualidades de Garrincha como jogador não podemos apenas pensá-lo como um atleta de conduta indisciplinada. O que está em jogo aqui é que Garrincha talvez não seguisse uma moral ascética, qualidade associada à vida esportiva em geral. Castro (1995) parece transformar a "idéia de um apetite sexual descontrolado", suas fugas das concentrações, em indisciplina e em potência da natureza selvagem. Poderse-ia inferir, todavia, que a imagem da indisciplina e aversão às normas sociais e às do esporte servem como reforço - ainda que não consciente - para a racionalização do herói alegre e descontraído que representa Garrincha. O biografado parece ser um herói dionisíaco e brasileiramente antropofágico. Garrincha é a metonímia de um dos "brasis".

A genialidade do jogador fica ainda mais evidente quando os treinamentos são secundarizados para explicar o desempenho. O lado infantil e moleque do jogador ganha destaque. Castro (1995) descreve Garrincha tendo como pano de fundo a imagem cultural que fazemos de nosso futebol, isto é, o "bom nasce feito".

Aqui devemos insistir nas representações construídas por Castro (1995) sobre o dom em oposição ao esforço. O treinamento - elemento atribuído a Didi - opõe-se ao dom. Aquele que treina estaria próximo do modelo das normas e da disciplina, enquanto o que possui o dom seria criativo, cria ruptura. Castro (1995), ao apresentar Didi, ou mesmo Joel - jogador que disputou com Garrincha a posição de titular durante a Copa do Mundo de 1958 -, destaca a aplicação tática e a disciplina como elementos importantes no sucesso desses jogadores. Garrincha, em contrapartida, teria se destacado independentemente do seu esforço. O dom que possui seria preponderante para determinar seu futuro nos campos, a "virtude do seu futebol" tinha como fonte de inspiração a liberdade e a indisciplina. $\mathrm{O}$ autor, ao demarcar

Movimento, Porto Alegre, v. 15, n. 01, p. 169-191, janeiro/março de 2009. 
a identidade de um jogador que simboliza o "estilo nacional" de futebol, o faz em oposição ao "outro", nesse caso apresenta jogadores "esforçados", isto é, os "Caxias". Garrincha é o boêmio do futebol, os "outros", os esforçados, são seus burgueses (BOURDIEU, 1996). Como boêmio, consequentemente morre na fumaça etílica.

Garrincha, mesmo sendo titular do Botafogo por várias temporadas no futebol brasileiro, só seria considerado o maior ponta-direita do mundo na Copa do Mundo de $1958 .{ }^{16}$ Castro (1995) mostra as dificuldades enfrentadas pelo jogador para que pudesse jogar "o seu singular futebol". A idéia do "gênio incompreendido" ou de um estilo de futebol de vanguarda que ainda levaria tempo para consagrar-se fica explícito no texto a seguir:

\begin{abstract}
A depender de muitos em 1954, Garrincha não seria convocado nunca. Todos os domingos ele cometia o pior pecado que se podia atribuir a um ponta: driblava demais, queria jogar sozinho. [...] Uma crítica quase infalível às atuações de Garrincha pelo Botafogo era: "Mais uma demonstração estéril de seus talentos indiscutíveis como driblador" (CASTRO, 1995, p. 87, grifos nossos).

Zezé alimentara também a ilusão de instruir Garrincha a recuar para receber a bola e, se possível, dar o primeiro combate ao adversário que passasse por aquela zona - como ensinara Telê a fazer no Fluminense. Mas se pensara em transformar Garrincha num novo Telê - generoso, solidário, altruísta -, Zezé também desistiu [...] concluiu que Garrincha era à prova de instruções (CASTRO, 1995, p. 88).
\end{abstract}

Devemos aqui matizar o debate. Parte das críticas atribuídas ao estilo individualista de Garrincha não eram exclusivas a ele. $\mathrm{O}$ Brasil, naquela época, vinha de duas campanhas em que o futebol baseado na improvisação e no talento havia sido derrotado - Copas do Mundo de 1950 e 1954. Matérias recolhidas no Jornal do Brasil, periódico de grande circulação nacional, antes da disputa da Copa

${ }^{16}$ Garrincha ganha o título de melhor ponta-direita do mundo da imprensa européia após a conquista na Copa do Mundo de 1958 (CASTRO, 1995).

Movimento, Porto Alegre, v. 15, n. 01, p. 169-191, janeiro/março de 2009. 
de 1958, evidenciam um "clamor" por uma maior disciplina tática e uma maior preparação do time para o torneio. ${ }^{17}$ Podemos pensar que existia um descrédito na idéia de que o talento individual bastaria para vencer a competição. Os brasileiros deveriam aprender com os times europeus o valor da disciplina tática e do treinamento para competições internacionais.

Veremos mais adiante que, após a vitória da seleção brasileira na Copa do Mundo de 1958, as reportagens dos jornais apresentam uma inversão, passando a enfatizar a genialidade e o talento como elementos preponderantes para a vitória do selecionado brasileiro, secundarizando a preparação minuciosa realizada pela seleção brasileira para essa competição. Nesse momento, os dribles de Garrincha exemplificam a arte e a singularidade de nosso povo.

Apesar da desconfiança de muitos em relação às qualidades de Garrincha, ele é convocado para disputar a Copa do Mundo de 1958. Seria reserva de Joel. Este é descrito por Castro (1995), poder-se-ia dizer, como um "Caxias", um homem responsável que tinha na sua velocidade e na sua obediência tática seus grandes trunfos para manter-se como titular da equipe. Veremos que na disputa da vaga entre Joel e Garrincha teremos a consagração do segundo personagem.

Somando o período de treinamento e a participação na Copa de 1958, a seleção brasileira ficou reunida por 75 dias. Segundo Castro (1995), nunca houve uma preparação tão minuciosa para a participação em uma competição internacional até aquela época. Garrincha participou de todo o processo preparatório com os outros jogadores.

Garrincha foi reserva nas duas primeiras partidas do Brasil na Copa de 1958. Castro (1995) argumenta que foi uma decisão tática por parte do técnico brasileiro. Garrincha foi assim descrito por Paulo Amaral - preparador físico do Botafogo e da seleção brasileira de futebol:

\footnotetext{
${ }_{17}$ Ver matéria veiculada no Jornal do Brasil dias antes da estréia do time na Copa do Mundo "Brasil deve jogar de primeira sem fazer 'firulas' para fazer figura" (JORNAL do Brasil, 27 maio 1958, 2ํㅡㄹ caderno, p. 1). O lema adotado pela comissão técnica para essa Copa do Mundo foi "trabalho em equipe" (CASTRO, 1995, p.129).

Movimento, Porto Alegre, v. 15, n. 01, p. 169-191, janeiro/março de 2009.
} 


\begin{abstract}
"Não vai dar certo", disse Paulo Amaral. "Garrincha não seguirá a sua instrução. No Botafogo, durante a preleção tática, nós o mandamos ir jogar pinguepongue ou fazer outra coisa. É imprevisível em campo. Se tem o gol aberto à sua frente, é capaz de passar a bola a um companheiro. Ou, então, completamente sem ângulo, resolver chutar. Só faz o que lhe dá na cabeça no momento. Não é jogador de seguir instruções" (CASTRO, 1995, p. 155).
\end{abstract}

No terceiro jogo, uma decisão tática definiu, dessa vez, que Garrincha iria começar jogando. O Brasil enfrentaria o time da União das Repúblicas Socialistas Soviéticas (URSS). Era o "futebol científico" "em que os jogadores estavam preparados para correr 180 minutos e, depois, sapatear balaikas sobre os bofes dos adversários" (CASTRO, 1995, p. 158).

Garrincha teve atuação de destaque. Castro (1995) narra com emoção o início da partida.

\begin{abstract}
E ainda faltavam 87 minutos para o jogo acabar! A continuar daquele jeito, já havia russos contemplando uma temporada na Sibéria. Nunca o orgulho do "científico" futebol soviético fora tão desmoralizado, e pelo mais improvável dos seres: um camponês brasileiro, mestiço, franzino, estrábico e com as pernas absurdamente tortas. A anticiência por excelência, o anti-Sputnik, o anticérebro eletrônico ou qualquer cérebro.

[...] No Rio, grudado ao rádio, com lágrimas nos olhos, o Botafoguense Paulo Mendes Campos, que sempre considerava Garrincha um deus entre os mortais, via enfim que sua fé não fora um delírio: Garrincha era a prova de que "a mágica pode ganhar da lógica” (CASTRO, 1995, p. 165, grifos nossos).
\end{abstract}

O discurso identitário localiza o seu "outro", o mundo científico e civilizado, caindo por terra ante o subdesenvolvido Brasil. Castro (1995), nesse momento, parece esquecer, por completo, todo o trabalho de preparação realizado pelo time brasileiro para a competição, atribuindo a vitória brasileira à "magia" de Garrincha. A defesa do

Movimento, Porto Alegre, v. 15, n. 01, p. 169-191, janeiro/março de 2009. 
Brasil, que até aquele momento da competição não havia sofrido nenhum gol - iria permanecer assim até as semifinais - não é citada como responsável pelas vitórias da equipe. A imagem identitária do futebol brasileiro está vinculada a equipes ofensivas que vencem, apesar de não possuírem esquemas táticos defensivos organizados. O bom desempenho da defesa brasileira - objetivada nos números - é secundarizada a favor do valor qualitativo do ataque brasileiro, ainda que esse não fosse dos mais eficientes da Copa de 1958. Apesar de não possuir o melhor ataque da competição, são as jogadas individuais de Garrincha, Pelé e outros que ganharam destaque nas construções do autor e são editadas na memória apresentada na filmografia e na mídia em geral.

A despeito das nossas carências, o dramaturgo Nelson Rodrigues, ${ }^{18}$ em sua crônica sobre essa partida, declara que Garrincha teria dado uma lição aos brasileiros: nosso sucesso viria da aceitação daquilo que nos era peculiar, sem admirar ou invejar nada do estrangeiro. "A pura, a santa verdade é a seguinte: qualquer jogador brasileiro, quando desamarra de suas inibições e se põe em estado de graça, é algo de único em matéria de fantasia, de improviso, de invenção. Em suma: - temos dons em excesso" (ANTUNES, 2004, p. 224). Não havia motivos para o brasileiro sentir-se inferior. Também tínhamos o nosso Sputnik: Garrincha. Seu grande mérito era não se abalar ao confrontar-se com o estrangeiro. A estética do estilo de jogo de Garrincha pode ser lida como um alento a toda a nação brasileira. Nelson Rodrigues exalta a mestiçagem e o futebol-arte como elementos centrais da brasilidade, metonimizados em Garrincha. A deformação de suas pernas proporcionou ao brasileiro uma grande lição: a auto-aceitação. Assim como Garrincha, que não imitava ninguém e deixava os estrangeiros boquiabertos com seus dribles desconcertantes, a nação brasileira teria também seu futuro aberto para o desenvolvimento a partir do reconhecimento das suas peculiaridades e potencialidades. Esse é um discurso identitário presente na luta cultural entre aqueles que pensam que o desenvolvimento nacional deve basear-se na incorporação do

\footnotetext{
${ }^{18}$ Nelson Falcão Rodrigues nasceu em 23 de agosto de 1912 em Recife. Foi o redator principal da revista semanal Manchete Esportiva, além de escrever para o Jornal dos Sports. Suas crônicas sobre futebol mostram-se um bom espaço para refletir sobre a identidade e o caráter nacional do brasileiro. Cf. Antunes (2004).
}

Movimento, Porto Alegre, v. 15, n. 01, p. 169-191, janeiro/março de 2009. 
universalismo do modelo civilizatório e cosmopolita, e os que acreditam que se deve encontrar um modelo singular, original, baseado no espírito do povo. Essa contraposição parece ser própria dos países pós-coloniais (ARCHETTI, 2003).

Castro (1995) é exaustivo nos exemplos que relatam a disciplina quase militar que foi instaurada pela comissão técnica em 1958. Tudo teria sido previamente pensado para que os "erros do passado" não se repetissem. Porém, narrando as conquistas da seleção, o biógrafo enfatiza o dom e a arte dos brasileiros em oposição à disciplina dos europeus. ${ }^{19}$ As vitórias parecem secundarizar o esforço e a disciplina presentes na conquista. Se as derrotas lembram nosso atraso em relação ao "outro" desenvolvido e civilizado, as vitórias apagam a competência de planejar e usar bem os conhecimentos desenvolvidos em função da criatividade essencializada na identidade do futebol brasileiro.

O Brasil venceria, na Copa de 1958, a França pelas semifinais e na final a Suécia. Garrincha teve excelente performance nos dois jogos e voltou para o Brasil consagrado como o melhor ponta-direita do mundo, título dado pela imprensa européia. A identidade é sempre relacional e necessita ser construída ou reforçada pelo olhar do outro.

Entre os anos de 1958 e 1962 Garrincha esteve no auge da sua forma física. O time do Botafogo foi bicampeão estadual, e a equipe foi a base da seleção brasileira que disputaria a Copa de 1962. O biógrafo, em diversos momentos do livro, busca desconstruir, trazendo à tona a "verdade", algumas histórias que foram atribuídas a Garrincha. Estas, em geral, descrevem Garrincha como um homem humilde, ingênuo e por vezes tolo. ${ }^{20}$ Castro (1995), em suas linhas, traça um outro perfil do jogador: um homem simples, porém perspicaz. Observemos que essa representação tem uma eficácia na cultura brasileira, por exemplo, parte da imagem do presidente Luiz Inácio da Silva foi

\footnotetext{
${ }^{19}$ Para legitimar seus adjetivos após as vitórias da seleção brasileira, Castro (1995, p. 166) cita reportagens de jornais estrangeiros que também realçam os feitos de Garrincha e outros jogadores da seleção nacional: "Parábens Gotemburgo. Na quinta-feira vocês verão Garricnha outra vez!", "O maior reserva do mundo" e "Garrincha teria derrotado a Inglaterra sozinho". ${ }^{20}$ Diz Castro (1995, p. 261): "Sandro e Mario Filho não calculavam que essas histórias seriam repetidas, deturpadas e que, com elas, estava se criando o mito de um gênio infantil, e quase debilóide, que não fazia justiça a Garrincha".
}

Movimento, Porto Alegre, v. 15, n. 01, p. 169-191, janeiro/março de 2009. 
construída, durante sua campanha à Presidência da República nas eleições de 2002, a partir das representações do homem humilde e perspicaz. Astúcia, simplicidade e pobreza estão juntas na literatura universal.

Garrincha disputou a Copa do Mundo de 1962 em uma condição bem diferente se compararmos com a copa anterior. Era uma unanimidade no país e sua convocação era certa. O time, assim como em 1958, preparou-se de forma exemplar para disputar a competição: "Os jogadores estavam fanaticamente compenetrados para ganhar o bi. Não reclamaram sequer da ginástica duríssima de Paulo Amaral" (CASTRO, 1995, p. 249).

Logo no segundo confronto contra a seleção da ex-Tchecoslováquia, a seleção perdeu seu maior craque, Pelé. O autor mostra que a saída de Pelé fez emergir uma liderança até então desconhecida em Garrincha. "Contra a Inglaterra, Garrincha saiu de sua posição, enfiou-se pelo meio e, para espanto dos ingleses, desempenhou tarefas que caberiam a outros" (CASTRO, 1995, p. 253).

No dia 9 de junho, o Brasil venceu a copa. Era a consagração definitiva não apenas de Garrincha como também do futebol brasileiro. Todos, após esse feito, queriam ver Garrincha. O Botafogo a partir do sucesso de Garrincha passou a lucrar alto nas excursões que fazia pela América do Sul e Europa. Castro (1995) ressalta que a presença de Garrincha garantia cotas maiores, em geral $50 \%$ mais altas.

Garrincha ainda ganharia o bicampeonato estadual para o Botafogo no ano de 1962, tendo atuação de destaque na final. Castro (1995) relata mais uma vez os desentendimentos de Garrincha com os dirigentes do clube que não lhe pagavam o que pedira em salários e prêmios pelas vitórias.

Mas, no gramado, Garrincha não estava preocupado com isso. Estava jogando por ele não pelo Botafogo. A estrela solitária era ele, não o clube. A partir do terceiro gol, começou a fazer o que mais gostava - e que nunca mais conseguiria fazer: brincar de jogar futebol.

Não era mais uma decisão de campeonato. Era uma pelada, uma brincadeira, como as brincadeiras entre amigos em Pau Grande ou - se ele

Movimento, Porto Alegre, v. 15, n. 01, p. 169-191, janeiro/março de 2009. 
soubesse - numa aldeia fulniô (CASTRO, 1995, p. 278-279, grifo nosso).

A trajetória individual de Garrincha no Botafogo e na seleção acaba, na narrativa de Ruy Castro, por revelar um modelo de identidade do futebol que se pretende hegemônico contrapondo o dom ao esforço e à disciplina.

\section{Conclusão}

A narrativa construída por Ruy Castro sobre a trajetória profissional de Garrincha enfatiza a idéia do jogador que nasceu com o dom para o futebol. Seu talento é dado como inato, na medida em que o ambiente selvagem de sua infância e sua ancestralidade indígena foram bases para expressão de sua genialidade no futebol. Castro (1995), ao buscar nos "antecedentes étnicos" a explicação para a sua suposta inadequação às regras sociais e para a indisciplina no trabalho na fábrica ou na vida privada, revela que o modelo de futebol que Garrincha praticava expressava-se na direção de uma ruptura estética. $\mathrm{O}$ futebol de Garrincha seria exuberante e criativo tal qual sua origem indígena e o ambiente em que fora criado.

Cuche (1999, p. 182) lembra-nos que o importante, para a afirmação da identidade de um grupo, não é inventar os traços culturais distintos, "mas localizar aqueles que são utilizados pelos membros do grupo para afirmar e manter uma distinção cultural" em relação aos "outros". Castro (1995), para ressaltar a singularidade do futebol de Garrincha, dialoga com os "outros" no sentido de apresentar a distinção do jogador e da cultura brasileira. O gênio individual é coletivizado quando o biógrafo apresenta jogadores "esforçados", disciplinados ou o futebol "científico" para contrapor ao futebol exuberante, natural, alegre, irresponsável e moleque de Garrincha e do Brasil, o beautiful game. Na dimensão coletiva, Garrincha representa o mundo subdesenvolvido que fez cair por terra toda tecnologia das grandes potências européias (oriental-ocidental) por suas pernas tortas e a crença no seu dom natural. Essa é a imagem identitária que acaba por obscurecer todo o processo de treino, disciplina e empenho

Movimento, Porto Alegre, v. 15, n. 01, p. 169-191, janeiro/março de 2009. 
que Garrincha e outros jogadores da seleção brasileira tiveram na afirmação do futebol brasileiro no cenário mundial.

Mané Garrincha as a Symbol of the Brazillian

National Identity

Abstract: The objective of the article is to analyze

Garrincha's biography, a famous player, as an expression of an individual trajectory that embodies meanings about the Brazilian soccer and on "Brazilian people”. The empirical material is Ruy Castro's book (1995) "Estrela solitária: Um brasileiro chamado Garrincha". The lines writings by the author build the idea that Garrincha is gifted. Its talent is given as innate and it doesn't need to be improved. The indigenous ancestrality is key for the author to interpret the exuberance and simplicity of his game, as its contrary behavior to the social norms and the discipline in the soccer fields.

Keywords: Soccer. National Identity. Garrincha. Biography.

Mané Garrincha como síntesis de la identidad del fútbol brasilero

Resumen: El objetivo del artículo es analizar la biografía del ex jugador de fútbol Garrincha como expresión de una trayectoria individual que encarna significados colectivos sobre el fútbol nacional y sobre el "ser brasilero". Utilizamos como fuente el libro de Ruy Castro "Estrela solitária: Um brasileiro chamado Garrincha". El análisis demuestra que la biografía se transforma en un discurso identitario escencialista. La ancestralidad indígena es clave para interpretar tanto la exuberancia y simplicidad de su fútbol, como su comportamiento adverso a las normas sociales y a la disciplina en los entrenamientos. El don y éxito en el fútbol independen, en la lectura cultural realizada por el biógrafo, del entrenamiento, de la perseverancia y del perfeccionamiento.

Palabras-Clave: Fútbol. Identidad Nacional. Garrincha. Biografia.

Movimento, Porto Alegre, v. 15, n. 01, p. 169-191, janeiro/março de 2009. 


\section{REFERÊNCIAS}

ANTUNES, Fátima Martins Rodrigues. Futebol de Fábrica em São Paulo. São Paulo, 1992. Dissertação (Mestrado) - Faculdade de Filosofia, Letras e Ciências Humanas, Universidade de São Paulo. São Paulo, 1992.

. Com brasileiro, não há quem possa!: futebol e identidade nacional em José Lins do Rego, Mário Filho e Nelson Rodrigues. São Paulo: Editora da UNESP, 2004.

ARCHETTI, Eduardo. Masculinidades: fútbol, tango y polo en la Argentina. Buenos Aires: Antropofagia, 2003.

AUGUSTO, Sérgio. Botafogo: entre o céu e o inferno. Rio de Janeiro: Ediouro, 2004.

BARTHOLO, Tiago Lisboa. Na quadra e no campo: esporte e identidade nacional no Brasil. Rio de Janeiro, 2007. Dissertação (Mestrado) - Programa de Pós-Graduação em Educação Física, Universidade Gama Filho. Rio de Janeiro, 2007.

BOURDIEU, Pierre. As regras da arte: gênese e estrutura do campo literário. São Paulo: Companhia da Letras, 1996.

CASTRO, Ruy. Estrela solitária: um brasileiro chamado Garrincha. São Paulo: Companhia das Letras, 1995.

CUCHE, Dennys. A noção de cultura nas ciências sociais. Bauru: EDUSC, 1999.

DAMO, Arlei Sander. Do “dom” à profissão: uma etnografia do futebol de espetáculo a partir da formação de jogadores na França e no Brasil. Tese (Doutorado) - Programa de Pós-Graduação em Antropologia Social, Universidade Federal Rio Grande do Sul. Porto Alegre, 2005.

GUEDES, Simoni Lahud. O salvador da Pátria: considerações em torno da imagem do jogador Romário na Copa do Mundo de 1994. In: GUEDES, Simoni Lahud. 0 Brasil no campo de futebol: estudos antropológicos sobre os significados do futebol brasileiro. Niterói: EDUFF, 1998. p. 61-78.

HELAL, Ronaldo. As idealizações de sucesso no imaginário brasileiro: um estudo de caso. In: HELAL, Ronaldo; MURAD, M. Alegria do povo e Don Diego: reflexões sobre o êxtase de heróis do futebol. Pesquisa de Campo, Rio de Janeiro, UERJ, 1995.

HELAL, Ronaldo; SOARES, Antonio Jorge; LOVISOLO, Hugo. A invenção do país do futebol. Rio de Janeiro: Mauad, 2001.

HOLANDA, Sérgio Buarque. Raízes do Brasil. 20. ed. Rio de Janeiro: José Olympio, 1988.

LEITE LOPES, José Sérgio. A vitória do futebol que incorporou a pelada. Revista da USP, Dossiê Futebol, São Paulo, n. 22, p. 64-83, jun./ago. 1994.

Movimento, Porto Alegre, v. 15, n. 01, p. 169-191, janeiro/março de 2009. 
LEITE LOPES, José Sérgio; MARESCA, S. A morte da "alegria do povo". Revista Brasileira de Ciências Sociais, n. 20, p. 113-134, out. 1992.

MAUSS, Marcel. Sociologia e antropologia. São Paulo: EPU/EDUSC, 1974.

PROPP, Vladimir. Morfologia do conto maravilhoso. Rio de Janeiro: Forense Universitária, 1984.

SOARES, Antonio Jorge. Futebol, raça e nacionalidade no Brasil: releitura da história oficial. Rio de Janeiro, 1998. Tese (Doutorado) - Programa de Pós-Graduação em Educação Física, Universidade Gama Filho. Rio de Janeiro, 1998.

SOARES, Antonio Jorge; LOVISOLO, Hugo. Futebol: a construção histórica do estilo nacional. Revista Brasileira de Ciências do Esporte, Campinas, v. 25, n. 1, p. 129-144, 2003.

TOLEDO, Luiz Henrique. Didi: a trajetória da folha-seca no futebol de marca brasileira. In: SILVA, V. G. (Org.). Artes do corpo: memória afro-brasileira. São Paulo: Selo Negro Edições, 2004. p. 79-122.

VAZ, Alexandre Fernandez. Esporte e mitologia em três momentos de nossa identidade nacional. Verso Reverso, São Leopoldo, v. 16, n. 34, p. 19-35, 2002.

Movimento, Porto Alegre, v. 15, n. 01, p. 169-191, janeiro/março de 2009. 